\title{
The Business Anticipatory Ecosystem outside the "First World": Competitive Intelligence in South Africa
}

\author{
Marie-Luce Kühn \\ Extra-ordinary research scientist, mlm@ibis.co.za \\ North-West University, Private Bag X 6001, Potchefstroom, 2531, South Africa \\ Wilma Viviers \\ Research Professor and WTO Chair, wilma.viviers@nwu.ac.za \\ North-West University, Private Bag X 6001, Potchefstroom, 2531, South Africa \\ Nisha Sewdass \\ Professor, sewdan@unisa.ac.za \\ University of South Africa, Preller St., Muckleneuk, Pretoria, 0002, South Africa
}

Jonathan Calof

Professor, Telfer School of Business ${ }^{a}$; Extra-ordinary Professor ${ }^{\mathrm{b}}$; Leading Research Fellow ${ }^{c}$, calof@telfer.uottawa.ca

a University of Ottawa, 55 Laurier Avenue East, Ottawa, Ontario, K1N 6N5

${ }^{b}$ North-West University, 11 Hoffman St, Potchefstroom, 2520, South Africa

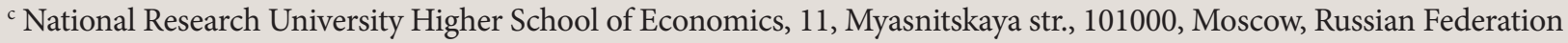

\begin{abstract}
$\mathrm{T}$ he purpose of this article is to extend the Competitive Intelligence (CI) business ecosystem concept and measurements, as developed by our previous work, to South Africa. The article is based on a pioneer study on the CI business ecosystem conducted outside North America and demonstrates how the concept and measurements are applicable in other countries.

The business ecosystem view considers the state of CI both in terms of intelligence practice (by firms) and the support system that enables firm practice. For this study, measures from past studies and additional revised measures were used to examine firms' CI practice as well as

CI supporting systems within government, academia, and professional associations.

Through multiple lines of research, the study noted that CI remains a practiced discipline in South Africa with evidence of the field having evolved within the country. While CI practices have grown in terms of some elements (for example, academic contribution), activities in other aspects of the ecosystem have declined such as association involvement, conferences, workshops, and training. Future research should be conducted to better understand the changes in these elements and their impact upon CI practice.
\end{abstract}

\section{Keywords:}

competitive intelligence; innovation; technologies;

strategies; business ecosystem; South Africa
Citation: Kuhn M.-L., Viviers W., Sewdass N., Calof J. (2020) The Business Anticipatory Ecosystem outside the «First World»: Competitive Intelligence in South Africa. Foresight and STI Governance, vol. 14, no 3, pp. 72-87.

DOI: $10.17323 / 2500-2597.2020 .3 .72 .87$ 
$\mathrm{R}$ esearching how organizations conduct their activities in Competitive Intelligence (CI) is a frequent area of research. In 2006, there was a survey of CI practitioners with a view to identifying how CI was being practiced [Fehringer et al., 2006]. In 2020, Crayon (a CI consulting firm) and SCIP (Strategic and Competitive Intelligence Professionals - a CI association) ${ }^{1}$ published "State of Competitive Intelligence", which looked at how CI was being practiced in 2019 on the basis of a survey of CI practitioners and others, including CI users [Crayon, 2020].

Competitive intelligence in this article is defined using the definition of the Society of Competitive Intelligence Professionals (SCIP). SCIP defines CI as "a systematic and ethical process for gathering, analysing and managing external information that can affect the company's plans, decisions and operations" [Mirum, 2020]. SCIP is the international representative professional body as well as the professional accreditation body. Therefore, as this is the association that defines what constitutes CI practice for accreditation purposes, it is their definition that we use.

Du Toit [Du Toit, 2015] in her study of past CI research studies looked at the similarities and differences between CI definitions, trying to find a common definition. She noted that there were several different definitions but there was enough commonality to come up with a core definition of "the process or practice that produces and disseminates actionable intelligence by planning, ethically and legally collecting, processing and analysing information from and about the internal and external or competitive environment in order to help decisionmakers in decision-making and to provide a com- petitive advantage to the enterprise." This is similar to the SCIP definition.

Using definitions similar to the one mentioned above, many researchers have developed surveys that look at how competitive intelligence is practiced. These surveys ask respondents to provide information on several dimensions of their competitive intelligence efforts including: the focus of CI projects, information collection activities, analytical techniques used, CI project management details, and the structure of their CI unit. Some of these CI practice studies are done at the global level (for example [Fehringer et al., 2006; Crayon, 2020]) and some of these are done at the country level (for example a study on CI practices in Israel [Barnea, 2016]). Some studies are sector-focused (for example on technology firms [Dishman, Calof, 2008]). Some use SCIP members as their sample frame so that the study looks at firms more likely to be practicing $\mathrm{CI}$, others use broad sample frames. Table 1 provides examples of the CI practice studies done.

While understanding how firms conduct CI is certainly important, this study focuses on the broader concept of the CI business ecosystem and the activities of the different organizations within this ecosystem. The business ecosystem originated with the work of Moore [Moore, 1993] who wrote that "a company should be viewed not as a member of a single industry but as part of a business ecosystem that crosses a variety of industries." In a business ecosystem, companies coevolve capabilities around a new innovation: they work cooperatively and competitively to support new products, satisfy customer needs, and eventually incorporate the next round of innovations. An ecosystem includes suppliers, dis-

\begin{tabular}{|c|c|c|c|c|}
\hline Study & Geographic focus & Industry focus & Sample & Firms \\
\hline [Fehringer et al., 2006] & Global & All & 550 & SCIP members \\
\hline [Dishman, Calof, 2008] & Canada & Technology & 1025 & All sizes \\
\hline$[$ Nasri, 2011] & Tunisia & $\begin{array}{l}\text { Communication \& technologies; } \\
\text { Manufacturing; Retailing }\end{array}$ & 8 & Large \\
\hline [Du Toit, Sewdass, 2014] & Morocco & All & 25 & All sizes \\
\hline [Sewdass, Du Toit, 2014] & South Africa & All & 24 & All sizes \\
\hline [Sewdass, Du Toit, 2015] & $\begin{array}{c}\text { Brazil } \\
\text { South Africa }\end{array}$ & All & 37 & All sizes \\
\hline [Barnea, 2016] & Israel & All & 39 & Large \\
\hline [Garcia-Alsina et al., 2016] & Spain & Education & 14 & Large \\
\hline [Munoz-Canavate, Alves-Albero, 2017] & Spain & All & 47 & Large \\
\hline [Drieman, 2018] & Global & All & 408 & All sizes \\
\hline [Calof et al., 2018] & Europe & All & 156 & $\begin{array}{l}\text { All sizes - } \\
\text { generally SCIP }\end{array}$ \\
\hline [Crayon, 2020] & $\begin{array}{l}\text { Primarily North } \\
\text { America }\end{array}$ & All & 1000 & All sizes \\
\hline
\end{tabular}

Available at: www.scip.org, accessed 29 February 2020. 
tributors, consumers, government, processes, products, and competitors. Being a part of a business ecosystem provides mechanisms to leverage technology, achieve excellence in research and business competence, and compete effectively against other companies. Organizations in a business ecosystem are involved in the delivery of a specific product or service through both competition and cooperation [Hayes, 2019]. The idea is that each entity in the ecosystem affects and is affected by the others, creating a constantly evolving relationship in which each entity must be flexible and adaptable in order to survive as in a biological ecosystem. Several other studies also found the ecosystem concept useful for their specific environments, for example [Hult et al., 2020, p. 38] defined the international business ecosystem as "the organisms of the business world - including stakeholders, organizations, and countries - involved in exchanges, production, business functions, and cross-border trade through both marketplace competition and cooperation."

It is our view that past studies, by focusing only on examining the CI practices of companies that practice competitive intelligence, miss out on those elements of the business ecosystem that are required to reinforce this CI practice. For example, academic research helps create new CI practices and university CI courses can help to develop practitioners. Glitman stated "Academic excellence and practical knowledge are key drivers in the advancement of the competitive intelligence profession" [Glitman, 2010]. Academia also supports CI practice by providing CI executive educational programs [Calof, Vibert, 2018]. In competitive intelligence, SCIP (CI association) provides practicing firms with standards (body of knowledge, certification), materials to help with setting up intelligence structures, train- ing, conferences, ethical guidelines, and so forth. The CI business ecosystem has supporting businesses - service providers, for example consulting firms that CI practitioners turn to for outsourcing CI projects or elements of the intelligence process. Figure 1 is a graphical representation of the CI business ecosystem concept being studied in this paper.

This broader view of the competitive intelligence business ecosystem is evident in how SCIP describes and classifies its members: competitive and market intelligence professionals, solutions providers, professors, students, and non-profit experts. The Crayon report classifies respondents as CI consultant, CI practitioner (CI is part of their role), and CI user [Crayon, 2020]. Further, asking CI practitioners if they use elements of the business ecosystem is common in CI practice surveys. For example, Fehringer et al. asked participants about their use of consultants (outsourcing research or analysis), acquisition of information (from outside vendors), and about training [Fehringer et al., 2006]. Yet despite this (the business ecosystem questions in surveys, association classification of business ecosystem in membership) most CI studies have focused only on understanding the organizations that are practicing competitive intelligence, the firms and not the CI business ecosystem. Only two Canadian studies were found that looked at the CI business ecosystem [Calof, Brouard, 2004; Calof, Vibert, 2018]. It is this gap in the literature that we seek to fill. To broaden the application of the CI business ecosystem beyond Canada.

The initial concept and measurements for the CI business ecosystem were developed in Canada [Calof, Brouard, 2004]. These were further refined in [Calof, Vibert, 2018]. While many of the concepts and measurements in the 2004 study were used in the 2018 study, several new measures were added in

\section{Figure 1. Competitive Intelligence Business Ecosystem Linking CI Practice and Support Variables}

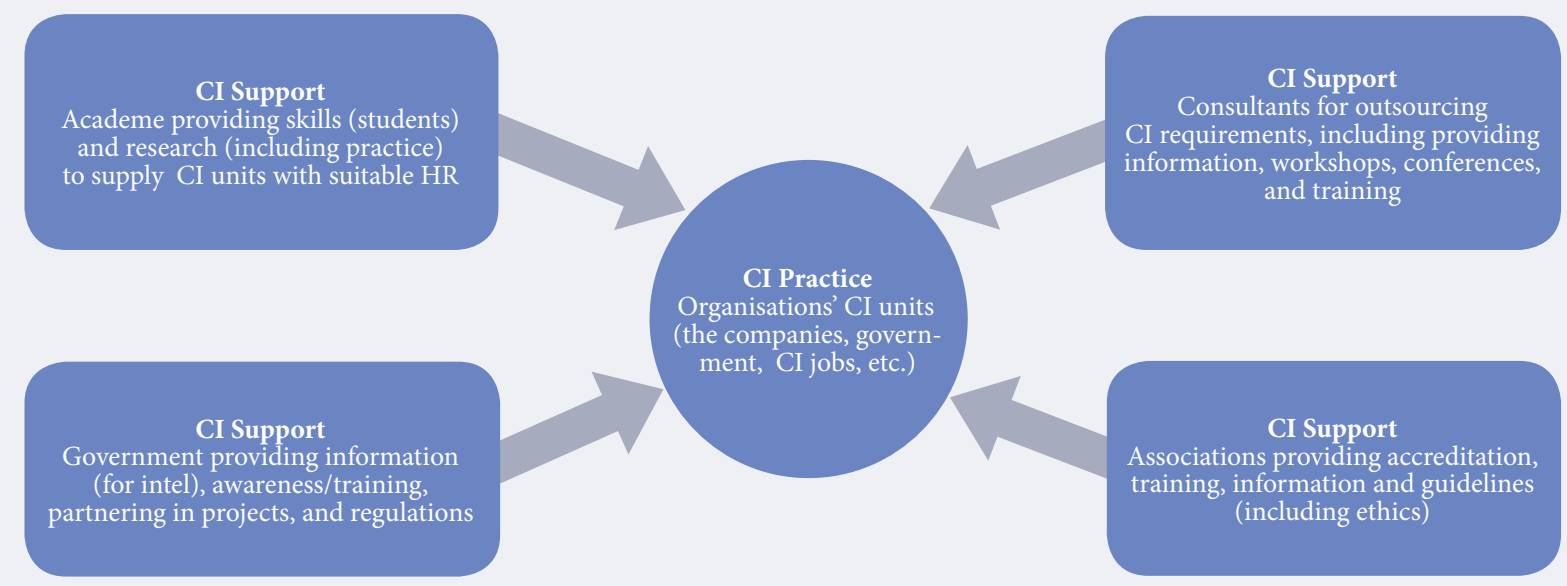

Source: authors. 
Table 2. Concept and Measurement of the CI Business eEcosystem

\begin{tabular}{|c|c|c|}
\hline & [Calof, Brouard, 2004] & [Calof, Vibert, 2018] \\
\hline Ecosystem variable & Concepts and Measurement & $\begin{array}{l}\text { Additional/revised measures and concepts } \\
\text { from } 2004 \text { study }\end{array}$ \\
\hline \multicolumn{3}{|c|}{ Ecosystem: CI practice } \\
\hline & $\begin{array}{l}\text { - Extent of corporate CI practice (from past } \\
\text { surveys and expert panel) } \\
\text { - Descriptions of federal and provincial } \\
\text { government CI programs (historical review and } \\
\text { expert panel) }\end{array}$ & $\begin{array}{l}\text { - Number of help-wanted ads in Canadian job search } \\
\text { engines mentioning CI } \\
\text { - Number of LinkedIn profiles mentioning CI } \\
\text { Existence of government (provincial and federal) CI } \\
\text { programs search using government search engines }\end{array}$ \\
\hline \multicolumn{3}{|c|}{ Ecosystem CI support } \\
\hline Consultants & $\begin{array}{l}\text { - Names of academics as consultants } \\
\text { - Description of consulting firms } \\
\text { - Names of independent consultants } \\
\text { - Exaining programmes on CI } \\
\text { - Expert panel }\end{array}$ & \\
\hline Academic & $\begin{array}{l}\text { - Academics in Canada involved in CI - From } \\
\text { industry consultation, SCIP members database, } \\
\text { and academic journal search engines } \\
\text { - Number of research contributions - Industry } \\
\text { consultation and academic publication search } \\
\text { engines } \\
\text { - Names of universities and colleges with courses } \\
\text { for students on CI - Industry consultation } \\
\text { - Universities and colleges with courses for } \\
\text { practitioners on CI Industry consultation }\end{array}$ & $\begin{array}{l}\text { - CI streams in Canadian academic conferences - } \\
\text { Industry consultation } \\
\text { - Number of names of Canadian CI academics } \\
\text { recognized in international rankings - Article } \\
\text { review, Industry consultation } \\
\text { - Courses that include CI in them - Industry } \\
\text { consultation } \\
\text { - Changes in methodology } \\
\text { - Courses found by searching websites of Canadian } \\
\text { universities }\end{array}$ \\
\hline $\begin{array}{l}\text { Government CI } \\
\text { support }\end{array}$ & $\begin{array}{l}\text { - Identification of government programs/agencies } \\
\text { that provide information and intelligence to other } \\
\text { firms } \\
\text { - Provision of CI training and conferences for } \\
\text { Canadian firms } \\
\text { - Joint intelligence programs } \\
\text { - Industry consultation }\end{array}$ & $\begin{array}{l}\text { - Searching for articles about government CI } \\
\text { programs } \\
\text { - Role conceptually broken down into CI partner } \\
\text { (joint projects), skills builder (offering training } \\
\text { - Methodology addition: Government search engines }\end{array}$ \\
\hline CI association & $\begin{array}{l}\text { - Number of SCIP members (SCIP members } \\
\text { database) } \\
\text { - Number of SCIP chapters (SCIP website } \\
\text { SCIP events (SCIP website and consultation) }\end{array}$ & - Special Library Association CI division membership \\
\hline
\end{tabular}

an attempt to obtain more in-depth insights. For example, in looking at CI practice (firms and government), the researchers expanded their measurement to include competitive intelligence jobs. The CI association went beyond SCIP to include CI-related associations like the Special Librarians Association (SLA) CI division. Table 2 provides the CI business ecosystem variables used in the 2004 study and the additions/changes made in the 2018 study.

The 2018 study made greater use of online sources of information than the 2004 study did, including government search engines and job search engines, as well as broader academic article search engines. The study reported on in this article seeks to use the concept of the competitive intelligence business ecosystem to study and provide readers with details of the CI business ecosystem in South Africa. In addition, as this is the first study on the CI business ecosystem in Africa - and South Africa specifically - the article seeks to enhance the generalizability of the concept and its measurement.

\section{Overview of Study Methodology}

In adopting the broader CI business ecosystem view of competitive intelligence, this study looks at the various elements of the CI business ecosystem, each with its own separate methodology. These methodologies are described in detail in the appropriate sections of this article. This section provides an overview of the methodologies used. In general, however, the methodology used is consistent with the Canadian studies mentioned earlier.

To explore how South African firms practice competitive intelligence, a review of studies in the past few years was conducted on South African firms' CI practices. In addition, this article reports on South African firm results from the global CI study described in [Calof et al., 2018]. A review was also conducted on CI activities in government by doing a web search of South African national and regional government websites. CI jobs were examined by searching South African job search engines and LinkedIn profiles.

The South African academic contribution to CI was researched using multiple approaches. CI research was examined by searching academic article databases (for example, Scopus, Web of Science EDS and ProQuest) for peer-reviewed research articles written by academics in CI. University CI courses were examined by going to all South African postsecondary institutions' websites and searching for CI courses. 
CI consultants were identified by searching the in ternet and using an expert panel.

Training courses, workshops and conferences as found in the Canadian study can be associated with association activity, consultants, and academe therefore to identify courses, workshops, and conferences, the expert panel was consulted and searching on the internet was done.

To identify government involvement in competitive intelligence including both CI practice and support, government search engines were used, examination of government websites, and consultation with the expert panel.

For the most part, these variables and their measurement are similar to those used in [Calof, Brouard, 2004; Calof, Vibert, 2018]. For more detail, see the methodology section for each part of the CI business ecosystem.

Readers will note several anecdotal and qualitative statements concerning CI associations, CI conferences, and other CI infrastructure elements. These were generated during an expert panel discussion involving a group of acknowledged South African CI experts. This group included:

1) One of South Africa's first CI consultants;

2)A South African CI academic acknowledged to be one of the top CI publishers in the country who was also a SCIP chapter chair for many years, a SCIP board member, and a board member of the African Economic Intelligence Forum;

3)A South African academic associated with early research on CI in South Africa who was also involved in the founding of the first SCIP chapters in South Africa.

4)A foreign professor who is an adjunct professor at a South African university. The foreign professor helped to start the Cape Town and Johannesburg SCIP chapters and participated in many of the early conferences in South Africa. Additionally, the foreign professor provided training at South African companies and government agencies and was among the first academics to study South African competitive intelligence practices.

\section{Practices in Firms}

The CI practice of South African firms was studied in two ways. First, a review was conducted of those studies that looked at CI practices in South Africa. Only those articles published in the years 2014-2019 were used so as to ensure that only recent practice was reflected. Secondly, South African firms were sent a survey designed to identify their CI practices. ${ }^{2}$ As there were few SCIP members in South Africa (the primary sample frame in the global study was SCIP members), the survey was administered at a CI conference held at the University of South Africa (UNISA) in Pretoria and also sent out to those who the researchers knew had CI units. Since there is "no recognized list of practicing CI professionals" in South Africa [Muller, Viviers, 2004], the universe is not known. To determine the situation with relation to jobs, help-wanted advertisements were searched using the expressions "competitive intelligence" or "market intelligence" or "business intelligence" in the job title or as a key responsibility. The jobs searched for therefore had to involve CI or had to have CI in the job description. The exact phase "competitive intelligence" was then used to determine how many persons have CI in their job title.

\section{Who is Practicing Competitive Intelligence?}

CI has long been recognized in South Africa as a strategic management tool that can enhance competitiveness [Sewdass, Du Toit, 2015] and many South African firms have been found in past studies to be practicing CI to survive in the midst of intense global competition [Sewdass, Du Toit, 2014]. The Industrial Classification, as discussed in the study by [Fehringer et al., 2006, p. 122] was used in the current survey to determine the various sectors that the respondents came from.

In terms of the kinds of companies that practice CI, in South Africa, CI was mainly practiced by "forprofit" firms, with limited evidence of CI being practiced by non-profit organizations [Sewdass, Du Toit, 2014]. Respondents in their study came from the following sectors: Financial, insurance, real estate and business services (25\%); Agriculture, hunting, forestry and fishing (15\%); Electricity and water supply (10\%); Tourism (10\%); Oil and gas (10\%).

The survey of CI practices (which is referred to in this section as the 'current survey') noted that the respondents came from a broad range of industries, including: Financial (20\%); Consumer goods and services (14\%); and Telecommunications (10\%). Government respondents were also represented $(14 \%)$ as were those in education $(10 \%)$.

In terms of firm size, it was mainly the larger firms with more than 500 employees $(50 \%)$ that were practicing CI [Sewdass, Du Toit, 2014]. However, they did note that smaller firms with fewer than 50 employees were also practicing CI (10\%). The practice of CI by smaller enterprises in South Africa was also noted by [Nenzhelele, 2016]. The current survey found that $14 \%$ of the firms practicing CI had fewer than 50 employees, $14 \%$ had between 50 and 249 employees, $19 \%$ had between 500 and 1,000 employees, $29 \%$ had between 1,000 and 10,000 employees, and $24 \%$ had more than 10,000 employees.

\footnotetext{
The survey design and testing approach as well as the methodology for the study are also described in detail by [Calof et al., 2018]. A copy of the survey can be obtained from the corresponding author.
} 


\section{How Formal is CI Practice?}

The studies [Sewdass, Du Toit, 2014, 2015] found that the majority of respondents $(60 \%)$ had a formal CI function at their firms that had been in existence for five years. However, they reported that there appeared to be a degree of complacency and self-deception that was inhibiting managers from implementing effective plans to improve their CI. Few conducted CI in a formal, systematic manner or had actual plans to improve their ability to keep track of competitors with a view to enhancing their competitiveness.

In the current survey, $86 \%$ of the respondents indicated some kind of formal CI structure. Of these, $43 \%$ said that it was centralized, $14 \%$ said that it was decentralized and $29 \%$ said it had a mixed structure (a structure in which some activities were centralized and some intelligence activities were performed independently by other departments). The most frequently mentioned units responsible for CI-related activities were market insight (29\%), marketing or marketing research (29\%), strategic planning (24\%), and CI (19\%).

One-third of respondents indicated that they had more than one unit at the firm performing CI and CI-related activities. CI units had been in existence for between six and ten years. In terms of the structure of the CI unit, the recent study reported that they had on average 2-4 employees, $52 \%$ had a formal CI strategy, $62 \%$ had formal CI procedures, $57 \%$ had ethical guidelines specifically for CI activities, and $62 \%$ had a manager with CI responsibilities.

\section{How is CI Practiced?}

According to [Sewdass, Du Toit, 2014, 2015] it was reported that South African intelligence practice had the following characteristics:

- CI was focused on government legislative trends (50\%), on decision-making (25\%), on helping to quantify/qualify strategic sources $(20 \%)$, and on monitoring competitor actions (17\%).

- The most prominent secondary sources used for CI include information on regulatory bodies, promotional materials, internal financial information, and corporate websites.

- The most prominent primary sources used in South Africa for CI include industry experts, direct customer feedback, company employees, and staff who attend conferences and seminars.

- The most frequently used analytical methods or models were industry analysis (50\%) and SWOT analysis (50\%), followed by GAP analysis (35\%), benchmarking (35\%) and competitor analysis (35\%).

- The methods used to distribute and present CI findings were presentations (27\%), e-mail $(27 \%)$, reports $(23 \%)$, personal delivery $(23 \%)$, and briefings.
These findings were largely confirmed by the study [Nenzhelele, 2016] on CI practices of small South African firms in the property sector. Customers were the respondents' main source of information for CI. Teamwork and brainstorming, a SWOT analysis, and valuation techniques were widely used by the real estate agencies to analyze the collected information. Respondents indicated that the preferred methods for disseminating the intelligence developed was through face-to-face meetings, e-mails, and presentations.

The study [Du Toit, 2015] revealed that large sums of money are already being spent on the processing and retrieval of information about the external business environment (including but not limited to customers, competitors, government, and technology). However, this does not mean that the quality of external environmental business information systems in South Africa is adequate, since only $28 \%$ of the respondents indicated that they had a formal environmental scanning system. Environmental scanning is a systematic process of determining the information needs of managers, making sure that the right information is collected and analyzed and applying the results in the strategic planning process [Du Toit, 2015]. This means that relatively little formal environmental scanning was undertaken by South African firms. In the current survey, when respondents were asked the percentage of time allocated to different parts of the external environments, the highest scores related to customers (36\% of CI time) and competitors ( $18 \%$ of CI time).

The current survey has several questions that ask about the CI focus (intelligence topics), collection sources, analytical techniques used, how intelligence was communicated, and how intelligence activities were managed. The findings revealed that, overall, $20 \%$ of intelligence time was spent in planning-related activities, $27 \%$ in collections, $22 \%$ in performing analytical activities, $11 \%$ in communicating the results, and $20 \%$ of time devoted to CI projects was spent in CI management activities, including evaluation. In terms of planning, the CI focus was predominantly to help make corporate or business decisions of a strategic nature, followed by decisions concerning market entry and sales and business development. Consistent with this, CI focused on market and industry reports and company profiles.

In terms of collection activities, the current survey found that the internet and customers were the most important sources of information for the respondents. However, most of the information sources were viewed as important to the respondents, with nine out of the eleven sources averaging between 2.7 and 3.2 in terms of importance on a four-point scale, with zero being not important and four being very important (internet, customers, publications, industry experts, internal databases, company employees, commercial databases, social media, and suppliers 
being at 2.7 to 3.2 ; government employees and association employees being at 2.3 and 1.9).

In terms of analysis, $84 \%$ of respondents indicated that they did some formal analysis, with the average number of techniques being 4.4. The most frequently used technique was SWOT (strengths, weaknesses, opportunities, and threats) analysis. The top five techniques noted were SWOT, followed by competitor analysis, financial analysis, bench-marking, and scenario analysis. Customer satisfaction (the users of CI) was the top method used to evaluate CI.

\section{Jobs in CI}

To assess "CI jobs", a web search of job advertisements was conducted in February 2020. Help-wanted databases were searched that had jobs containing the expressions "competitive intelligence" or "market intelligence" or "business intelligence" in the job title or as a key responsibility. "Market intelligence" and "business intelligence" are used rather than just "competitive intelligence" because these other expressions were noted in other parts of this study. For this web enquiry, the authors used the phrase "Competitive Intelligence" first with the phrase "South Africa" and then with the names of each of the nine provinces in South Africa. The enquiry was done on February 18, 2020 on three job sites, i.e. CareerJet, LinkedIn.za, Indeed.Za, and PNet.co.za. The jobs searched for therefore had to involve CI or had to have CI in the job description. The first 200 job advertisements on each of these websites were analyzed, meaning that a total of 800 profiles were analyzed.

In order to widen the search, the authors also used the phrases "Competitor Intelligence" and "Market Intelligence" in conjunction with "South Africa" on the job sites LinkedIn.za, Indeed.Za, and PNet.co.za.

Finally, to determine the number of people who are currently practicing CI, LinkedIn was searched to identify people who have the exact phrase "competitive intelligence" in their title. The search phrase "competitive intelligence manager" was entered, together with Johannesburg, Durban, Pretoria, or Cape Town (the four main economic hubs in South Africa). The reason for entering these hubs is that the search would yield more accurate and narrower results. The first 200 LinkedIn profiles on each of the hubs, i.e. a total of 800 profiles, were scanned to extract those that had "competitive intelligence" as an exact phrase in their job titles. The results are summarized in Table 4. No job classification was used; rather, jobs databases were searched using specific terms. These terms would generate results which included job titles. These job titles would be the ones written by the hiring organization or the hiring company.

The majority of CI and CI-related job opportunities appeared in the main economic areas in South Africa, i.e. (in terms of population number, descending order) Cape Town, Durban, Johannesburg, and Pretoria. ${ }^{3}$ Only a few of these were for jobs with CI in their title. However, most had CI as part of the skill requirement or job development and most job names were related to business development, market insights, and strategic management. To a lesser degree, information specialist/knowledge management jobs were found in the search.

The job searches on each site resulted in around 20 jobs each. On Indeed and CareerJet, the job search yielded 23 and 20 jobs respectively in South Africa which had CI in the job description and/or title. PNet yielded 19 results using the same phrases and words. There was overlap and so it is not possible to state that these jobs were unique. Using the results of Indeed, most of these jobs (13) were in Gauteng, seven in the Western Cape, and two in KwaZuluNatal. A similar number dispersal was found in the results for PNet and CareerJet. The industries in which CI featured most in the job descriptions were banking and finance, manufacturing, pharmaceuticals, and services.

The results indicate that $\mathrm{CI}$ is pervasive but is notable for being a demarcated by specialization. The Indeed.co.za findings point to CI in job descriptions in a variety of industries. The industries featuring most prominently in the results were (in order of descending size) engineering and automotive (6), banking and finance (2), real estate (3), logistics (1), ICT (3), and retail/FMCG (3). Jobs with $\mathrm{CI}$ as a key responsibility were also available in human resources, public sector, utilities, and mining. Many of the jobs had the words market, sales, or marketing in their title. A similar pattern was found on PNet.co.za and CareerJet using the same methodology.

While the jobs identified in the research did not contain the phrase "competitive intelligence" in their title, the description in the key responsibilities all pointed to the incumbent having to understand or monitor or collect from and analyze the competitive landscape. The key responsibilities on Indeed, PNet, and LinkedIn all included "competitive intelligence" or competitors/competitor intelligence/competitive analysis and also contained the following descriptions: Market and CI; track CI and monitor competitor activities. The most prominent job titles that had CI among the key responsibilities are:

${ }^{3}$ Available at: www.geonames.org/ZA/largest-cities-in-south-africa.html, accessed 8 February 2020 


\section{Table 3. Job Titles Containing the Phase "Competitive Intelligence"}

\begin{tabular}{|l|l|l|}
\hline Job Title & Industry & Location \\
\hline $\begin{array}{l}\text { Competitive Intelligence } \\
\text { Manager } \\
\text { Providing CI services at } \\
\text { a large financial company }\end{array}$ & Banking & Johannesburg \\
\hline $\begin{array}{l}\text { Competitive Intelligence } \\
\text { Manager } \\
\text { Competitor analysis for } \\
\text { a large bank }\end{array}$ & Banking & Johannesburg \\
\hline $\begin{array}{l}\text { Competitive Intelligence } \\
\text { Analyst } \\
\text { Commissioned CI research } \\
\text { for the market }\end{array}$ & Consulting & Johannesburg \\
\hline $\begin{array}{l}\text { Competitive Intelligence } \\
\text { Analysis Expert } \\
\text { Group CI services - } \\
\text { competitor and trends } \\
\text { analyst }\end{array}$ & Pharmaceutical & Johannesburg \\
\hline $\begin{array}{l}\text { Manager: Competitive } \\
\text { Intelligence } \\
\text { Provides CI services to the } \\
\text { market }\end{array}$ & Consulting & Johannesburg \\
\hline $\begin{array}{l}\text { Competitive Intelligence } \\
\text { Analyst } \\
\text { CI services to client base of } \\
\text { a large auditing firm }\end{array}$ & Auditing & Johannesburg \\
\hline $\begin{array}{l}\text { Competitive Intelligence } \\
\text { Analyst } \\
\text { Environmental scanning } \\
\text { and competitor analysis }\end{array}$ & Consulting & Cape Town \\
\hline Source: authors. & & \\
\hline
\end{tabular}

- Marketing Representative

- Executive Head: Research \& Insights

- Senior Business Analyst, Projects and Market Insights

- Chief Executive Officer

- Regional Manager

- Business Analyst (Strategy)

- Area Sales Manager

- Intelligence Processor

- Strategist: Strategy and Research

- Marketing Manager

- Sales/Outside Sales Representative

- Senior Account Executive

- Consumer Account Manager - SADC

- Public Sector Partnership Support

- Business Development Manager

With specific reference to CI practitioners, i.e., incumbents with the job title CI analyst or CI manager/practitioner on LinkedIn, there were only seven jobs nationally with that exact title. Whereas Johannesburg and Cape Town yielded seven results on February 18, 2020 (see Table 3), in Pretoria and Durban (capital of KwaZulu-Natal province) there was not a single person that had CI in their job title.

Table 4. Mentions of "Intelligence" Services on Provincial Government Economic Development or Trade Promotion Websites

\begin{tabular}{|c|c|c|c|}
\hline Location & Agency & Website & Description of relevant services \\
\hline Eastern Cape & $\begin{array}{l}\text { Eastern Cape } \\
\text { Development } \\
\text { Corporation }\end{array}$ & ecdc.co.za & $\begin{array}{l}\text { "Economic Intelligence" in support of its core business areas [ECDC, 2020]; } \\
\text { "market intelligence" for exporters }\end{array}$ \\
\hline Free State & $\begin{array}{l}\text { Free State Development } \\
\text { Corporation }\end{array}$ & fdc.co.za & No mention of the word "intelligence" on the FDC \\
\hline Gauteng & $\begin{array}{l}\text { Gauteng Growth and } \\
\text { Development Agency }\end{array}$ & ggda.co.za & $\begin{array}{l}\text { It has a "Business Intelligence and Planning business unit" with its } \\
\text { main service being "to improve the GGDA and the provinces ability to } \\
\text { conceptualise and implement targeted initiatives that will grow the key } \\
\text { sectors and sub-sectors of the economy and accelerate inclusive economic } \\
\text { growth" }\end{array}$ \\
\hline Limpopo & $\begin{array}{l}\text { Limpopo Economic } \\
\text { Development Agency }\end{array}$ & lieda.co.za & $\begin{array}{l}\text { LIEDA's mission is "to provide business intelligence and research and } \\
\text { development towards innovative solutions to develop scenarios and business } \\
\text { intelligence, monitor and evaluate the impact of projects, provide capacity } \\
\text { support in areas of development such as economic development research; be } \\
\text { a first point of call in terms of business and market intelligence" }\end{array}$ \\
\hline Mpumalanga & $\begin{array}{l}\text { Mpumalanga Economic } \\
\text { Growth Agency }\end{array}$ & mega.gov.za & $\begin{array}{l}\text { MEGA's Trade and Investments Division provides international market } \\
\text { information, intelligence and research. Trade advisors have market } \\
\text { intelligence and research as part of their key responsibilities }\end{array}$ \\
\hline $\begin{array}{l}\text { Northern } \\
\text { Cape }\end{array}$ & $\begin{array}{l}\text { Northern Cape } \\
\text { Economic Development, } \\
\text { Trade and Investment } \\
\text { Promotion Agency } \\
\text { (NCEDA) }\end{array}$ & nceda.org.za & $\begin{array}{l}\text { As part of its trade development and promotion services, the economic } \\
\text { development agency "supported by intelligence, will provide businesses } \\
\text { with a package of support to maximise opportunities that assists Northern } \\
\text { Cape clients meet the challenges and manage the risks of doing business in } \\
\text { international markets" }\end{array}$ \\
\hline North-West & $\begin{array}{l}\text { North-West } \\
\text { Development } \\
\text { Corporation }\end{array}$ & nwdc.co.za & No mention of the word "intelligence" on the NWDC website \\
\hline $\begin{array}{l}\text { KwaZulu- } \\
\text { Natal }\end{array}$ & $\begin{array}{l}\text { Trade and Investment } \\
\text { KwaZulu-Natal }\end{array}$ & tikzn.co.za & $\begin{array}{l}\text { Trade and Investment KwaZulu-Natal provides sector intelligence following } \\
\text { a multi-method approach within a business-to-business and business-to- } \\
\text { consumer market }\end{array}$ \\
\hline Western Cape & $\begin{array}{l}\text { Cape Town and Western } \\
\text { Cape Tourism, Trade } \\
\text { and Investment }\end{array}$ & wesgro.co.za & $\begin{array}{l}\text { "Business intelligence generated by its research teams to provide the leads for } \\
\text { engaging with foreign embassies, consulates, high commissions, stakeholders } \\
\text { and chambers of commerce - locally and abroad" }\end{array}$ \\
\hline
\end{tabular}


Many results, despite not having $\mathrm{CI}$ in the job title, do list competitive intelligence as a skill. However, this does not necessarily mean that the job requires skills in CI; it might be more about the person's skill set than a job requirement. The fact that jobs in South Africa that had CI in the job title were so few (7), but using the words competitor, competitive, and intelligence in a wider search yielded more results, point to the fact that $\mathrm{CI}$ is practiced more widely and in jobs that have titles other than the phrase Competitive Intelligence.

\section{Summary of CI Practices and CI Jobs in South Africa}

When comparing the CI practices of South Africa with those of other developing (emerging) countries such as Malaysia, Morocco, and Brazil, it was noted that CI practices were more mature in South Africa [Sewdass, Du Toit, 2014]. Analytical methods used in South Africa were more varied than those used in the other developing countries, which relied heavily on SWOT analysis and customers. However, when comparing the past studies on CI practices in South Africa with the current survey, it is interesting that SWOT analysis, competitor analysis, and benchmarking still remain the most frequently used techniques in South Africa.

The financial industries still dominate the sector where CI is practiced in South Africa. CI is also still practiced mainly by large companies with more than 500 employees (72\%), while the companies with fewer than 50 employees still continue to practice CI (14\%) in the current survey compared to $10 \%$ in previous studies. Thus, compared to studies of CI practice in other developing countries, it appears from the research that South African firms have more formal intelligence systems.

Also, in comparing past research with the current survey, it appears that CI is growing in South Africa, with more formalized practices. Finally, it is evident that as CI activity grows, the units responsible for it are becoming more diverse (market insight, for example, being the dominant unit name) with more and more firms having multiple units responsible for CI activities. CI jobs are found in all industries. While only few job titles contain the exact phrase "competitive intelligence" there is evidence of CI being practiced widely in jobs with various titles (see Table 3).

\section{Practices in Government}

The methodology used to assess CI practices in government involved a web search using the search terms "Competitive Intelligence" and "government" and "South Africa", as well as "Competitive Intelligence" and the names of the various trade and investment promotion organizations, including the largest state-owned enterprises (SOEs). The SOEs selected were those known to have CI practices. It should be noted that in South Africa, each of the nine provinces has a trade and investment promotion organization/agency. Each province, in turn, has a government economic department and/or a trade and investment-type organization as well as chambers of commerce funded through public and/or private funds. Over and above doing a general internet search, the authors also researched the websites of the economic development or trade and investment promotion organizations/agencies in all nine provinces.

In examining $\mathrm{CI}$ in government, the authors looked at two aspects: firstly, whether CI is practiced at the government level, and secondly, whether there is any government support for CI as a business discipline in South Africa. The latter was emphasized in a study [Pellissier, Nenzhelele, 2013] which found that CI is a critical success factor in the case of forprofit and non-profit, large and small, public and private firms.

In South Africa, the influence of the state in economic activity is particularly strong; hence, aggressive sponsorship of and the commitment of government leaders to CI campaigns and activities are crucial [Strauss, Du Toit, 2010]. Historically, however, the word "intelligence" has had negative connotations since South African intelligence activities were conducted by state institutions that were part of the apartheid machinery. Indeed, many of the first generation CI professionals and early consultants came from the National Intelligence Service, military intelligence, and government. This is similar to early CI consultants in the rest of the world who acquired their intelligence skills in formal government intelligence structures.

Moving the focus to whether CI is practiced at a government level, the results point to the fact that intelligence as a wider concept is still largely seen as a political and military effort in government departments in South Africa. There is some anecdotal evidence of intelligence being associated with competitiveness in some government documents, such as the South African Yearbook 2018/19 [GCIS, 2019]. However, when a search is conducted on the South African government websites using the term "competitive intelligence", there is no emphasis on CI at any government level - national, provincial, or lo$\mathrm{cal}$ - the emphasis is upon security intelligence and risk, and not on CI. Several departments including for example the Department of Trade and Industry (the DTI) and the Department of Agriculture, Forestry and Fisheries have CI programs and have undergone training including amongst others Trade Show Intelligence on an ad hoc basis. Within the DTI there is similar evidence of CI initiatives in the Industry and Export Associations. These initiatives are however not at a sufficient level to have resulted in department policies around them and therefore 
would not appear in a department policy search. Nevertheless, the expert panel was aware of several of these ad hoc CI initiatives within the government. The government intelligence focus mainly relates to vulnerability assessments, security risk management, governance, compliance, and corporate investigations aimed at ensuring systematic and coordinated analysis, and also highlighting the threats the firm faces, its inherent vulnerabilities, and appropriate counter and control measures for minimizing risks, both in the physical and the cyber security domains ${ }^{4}$ [Duvenage, 2020].

This is not to suggest that there is no purpose for CI at the various government levels (national, provincial, and local) as countries, provinces, and municipalities do compete for scarce resources and particularly investments (including foreign direct investment and associated skills). As mentioned, all nine provinces in South Africa have an economic and/or trade and investment organization/agency (within the specific provincial government structures). On the business and trade promotion organization level, the role and value of intelligence are more evident. All but two of these organizations mention CI, market intelligence, and/or business intelligence on their websites as part of the service rendered to their stakeholders (see Table 4).

The head of research at the Western Cape economic development agency (Wesgro) ${ }^{5}$ [Wesgro, 2020a], in a discussion with the author, indicated that Wesgro has CI services focused on market and industry research and that the Western Cape, Gauteng, and KwaZulu-Natal are the leading provinces in terms of market and business intelligence research services. These trade and investment organizations, however, emphasize that the research provided does not contain covert and sensitive competitor information because they need to remain impartial and also that their time and resource limitations do not permit this type of research for CI purposes.

At state-owned enterprises (SOEs) like the CSIR (Council for Scientific and Industrial Research, which is South Africa's central and premier scientific research and development organization), Denel (the largest manufacturer of defense equipment in South Africa), Telkom (an information and communications technology services provider in South Africa), Eskom (South Africa's public electricity utility), and SAA (the national airline), CI is practiced.

These SOEs traditionally had some of the largest CI units in the country. Eskom has a job advertisement on its website for a Senior Analyst Business Intelligence stating that the specialization is "to provide commercial intelligence through the Business Intel- ligence department with business and data analytics, procurement scorecards, market research, benchmarking, competitor identification screening and analysis, threats, and identification analysis" ${ }^{\text {[Es- }}$ kom, 2020]. In 2013, Eskom had 10 members that belonged to the SCIP South African Chapter. Eskom paid for the membership of its employees. This was indicative of the commitment of the company to practicing CI.

\section{Support Activities}

\section{Academe}

South African scholarly articles were identified by searching a variety of academic databases, including Google Scholar, Scopus, Web of Science, EDS, and ProQuest. This is similar to the methodology used by [Calof, Brouard, 2004] (see Table 2), which used the ProQuest and ABI Inform search engines to search for scholarly academic articles. These searches were conducted in February 2020. Keywords that were used were "South Africa" and "Competitive Intelligence" (CI).

These articles were then examined to ensure that the subject matter was competitive intelligence and that the author(s) was/were from South African institutions. This resulted in both a list of articles and a list of authors. This list of articles and authors was then sent to prominent South African CI researchers who were asked if they were aware of other publications or articles written by academics based at South African universities. With a validated list of those CI researchers/academics who had studied and published in competitive intelligence, the researchers then went back to the academic databases and searched for all publications from these authors to identify additional CI publications that each had published. The emphasis in this phase was to be as complete as possible in terms of identifying articles about CI from academics at South African research institutions (see Table 2).

The second part of the academic contribution to CI was to identify which institutions taught competitive intelligence - in a sense, the extent to which academic institutions were training CI practitioners. To this end, an examination was conducted of the websites of all 26 public universities and the seven universities of technology (formerly known as technical colleges or technikons) in South Africa. The search phrase "Competitive Intelligence" was used and the latest yearbooks (2020) and curricula for undergraduate and postgraduate programs were examined. South Africa's 26 public universities are all members of Universities South Africa. The web

\footnotetext{
4 Telephone interview, February 8, 2020.

Interview with Head of Research. (Personal communication, 27 February 2020).

Available at: https://secapps.eskom.co.za/sites/Recruitment/Pages/Senior-Analyst-Business-Intelligence(Megawatt-Park).aspx, accessed 12 February 2020.
} 
search was intended to establish whether CI is currently offered as a course at higher education institutions (see Table 2).

The research results relating to scholarly works on "Competitive Intelligence in South Africa" (1995-2019) can be summarized as follows:

- Between 1999 and 2017, there were 88 articles published in peer-reviewed academic journals by academics from South African research institutions.

- Ten academics had two or more articles, with the most articles coming from the following researchers: Muller, M.L. (33 - North-West University and IBIS Consulting), Viviers, W. (21 - North-West University), Du Toit, A.S.A. (18 - UNISA and University of Pretoria), Nenzhelele, T.E. (10 - UNISA) and Sewdass, N. (9-UNISA). Many of these articles were jointly written by two or more of the authors and therefore the total of 108 in Table 6 is more than the total number of articles of 88 .

- In terms of the focus of South African CI academic scholarship, 39 of the articles were of the country CI variety (looking at how CI is practiced in different countries or comparing countries to identify differences in CI practice).

- Thirty-one of the articles looked at CI practice in different sectors - thus industry-focused CI research (for example, how pharmaceutical companies practice $\mathrm{CI}$ ) or a specific company (case study).

- Twenty-three of the articles were focused on CI literature reviews (defining competitive intelligence and the domain).

- Nine of the articles looked at CI skills requirements.

- The remaining six articles looked at the interplay of knowledge management and competitive intelligence.

In terms of teaching-related activities, from 1995 to 2020 there were $13 \mathrm{PhD}$ theses and four Master's dissertations completed on CI in South Africa. There were six universities involved in supervision. The universities that conferred most of these degrees were: North-West University (5), University of Johannesburg (5), University of Pretoria (2), and University of the Witwatersrand (2).

CI as a course was first taught in South Africa in 2002 at one higher education institution. As of the study date, four higher education institutions offer some formal academic courses from undergraduate (Bachelor's degree) to postgraduate (Honours, Master's and $\mathrm{PhD}$ ) level and also at the certificate level. CI courses in South Africa are mainly offered as part of the curriculum in the Department of Information Science, the Department of Information and Knowledge Management, and the Department of Business Management.
The University of Pretoria was the first academic institution to recognize the need for formal academic training in CI. CI as a study field, with close links to information science and knowledge management, was offered at postgraduate and certificate levels by the University of Pretoria's Department of Information Science in 2002. It was taught by a consultant for the first two years. It was then developed and has been taught internally since then by university faculty with courses offered at both undergraduate and postgraduate levels. The aim of the course is to provide practitioners and students involved in this field with the necessary skills to contribute to the competitiveness and intellectual capital of their firms.

Similarly, the University of Johannesburg started teaching CI with consultants initially developing and presenting a short course in CI from 2003 until 2009. The university then started presenting inhouse, as is still the case.

Tshwane University of Technology (TUT) offered CI as part of their Advanced Knowledge Management course, which is a module in the Bachelor of Information Technology (BIT): Technology Business Applications qualification.

Table 5 summarizes CI in academia and the scholarly contributions and details of university CI courses. From the total of 88 articles published in the two decades between 1996 to 2015, the number of articles is 29 in the first decade (1996-2005) and 53 in the second decade (2006-2015), which indicates a significant increase of more than $80 \%$. Although it is not yet known what the number will be in the decade of 2016 to 2025, indications are positive. It is therefore clear that the number of articles for two decades have been growing substantially.

In addition, the business schools of various universities, such at the University of Pretoria's Gordon Institute of Business Science (GIBS), UNISA's School of Business Leadership (SBL), the University of Cape Town's Graduate School of Business, and North-West University Business School include CI as part of their module on strategy and have topics dedicated to CI but no specific module or research focus area.

Seminars and special lectures on CI are also presented at business schools, such as North-West University's Advanced Management Module which is an elective in the MBA program. In this regard, Professor Jonathan Calof gave a presentation on CI to students at the MBA summer school. Another example of a talk given on CI was "Building early warning systems: leveraging Competitive Intelligence in the data science age" presented by Scott Leeb of the Department of Information and Knowledge Management at the University of Pretoria.

Various ecosystem measures show that there has been an increase in academic activity and also demand for CI teaching at universities. CI courses are 
being offered at two higher education institutions, while in this study, four universities were found to offer formal CI courses, and Master's and/or PhD studies are currently offered at seven universities [Sewdass, Du Toit, 2014]. In addition, as pointed out in this section, many South African universities are offering competitive intelligence within other courses. In terms of demand for CI at the graduate level, UNISA reports that in 2019, 35 applications were received for the competitive intelligence focus area in the Master's and $\mathrm{PhD}$ programs and in 2020, 53 applications were received.

\section{Consultants, Training, Workshops and Conferences}

To assess the situation regarding CI consulting companies, a Google search was conducted in February 2020. The search phrases and terms used were "Competitive Intelligence", "consulting", and "South Africa." The websites of the firms identified were then examined to determine whether they were "CI" consultants. Furthermore, news media and other sources were examined to determine if a particular firm was in fact a CI consulting firm.

To identify CI training workshops and conferences in South Africa, a web search was conducted in February 2020, using the search terms "South Africa" and "Competitive Intelligence" and the words "training" and "conference." The results of this search yielded the names of training businesses and conference organizers. The websites of these firms were then searched to determine whether any CI training was being offered and whether any conferences were being organized.
In the early days of CI in South Africa (1990s and the early 2000s) [Muller, 1999; Viviers et al., 2002; Muller, Viviers, 2004], there were several consultancies that specialized purely in CI (consulting and training). The web search found fewer companies than were identified in the early 2000s. In fact, only two were identified that are primarily focused on competitive intelligence. Regarding these two CI consultancies, their services include consulting, training, and commissioned CI research.

Not only were fewer consultancies identified in our research, but those found were less focused on training than on consulting. However, while CI-focused consultancies are clearly fewer in number today than in the early days, several consultancies were identified that included intelligence-related activity among their service offerings. Similar to the large consultancies turning HR advice into KM advice, CI was absorbed into a wider research service offering, which is called Data Intelligence, Business Intelligence, Market Intelligence, or Big Data. Most concerning in terms of the CI ecosystem is that many of the pure CI consulting companies operating in the early days have ceased to exist.

On training, workshops, and conferences, the web search yielded zero results - in other words, there was no evidence of any training taking place or conferences being organized with CI as a theme in 2019/2020 (note that this study looks at the CI ecosystem of South Africa today). In comparison, in the early days of $\mathrm{CI}$, there were several training entities providing open platform CI training courses that enabled firms to develop CI

Table 5. Competitive Intelligence in Academe: 19952020

\begin{tabular}{|c|c|c|c|c|}
\hline Name of university & $\begin{array}{l}\text { Name of } \\
\text { researchers }\end{array}$ & $\begin{array}{c}\text { Author/ co-authorship in } \\
\text { articles }\end{array}$ & $\begin{array}{l}\text { Number of formal CI } \\
\text { courses }\end{array}$ & $\begin{array}{l}\text { Number of M \& PhD } \\
\text { degrees awarded }\end{array}$ \\
\hline North-West University & $\begin{array}{l}\text { Muller, M.L. } \\
\text { Viviers, W. }\end{array}$ & $\begin{array}{l}33 \\
21\end{array}$ & None & $\begin{array}{c}3 \mathrm{PhD} \\
2 \text { Master's }\end{array}$ \\
\hline University of Johannesburg & $\begin{array}{l}\text { Du Toit, A.S.A } \\
\text { Strauss, A.C. }\end{array}$ & $\begin{array}{c}13 \\
2\end{array}$ & $\begin{array}{c}1 \text { Undergraduate } \\
1 \text { Postgraduate } \\
\text { M \& PhD }\end{array}$ & $\begin{array}{l}4 \text { PhD } \\
1 \text { Master's }\end{array}$ \\
\hline University of South Africa & $\begin{array}{c}\text { Nenzhelele, T.E. } \\
\text { Sewdass, N. } \\
\text { Du Toit, A.S.A. } \\
\text { Maune, A. } \\
\text { Venter, P. } \\
\text { Tustin, D. } \\
\end{array}$ & $\begin{array}{l}10 \\
9 \\
5 \\
6 \\
2 \\
1 \\
\end{array}$ & $\begin{array}{l}\text { M \& PhD Research focus } \\
\text { area }\end{array}$ & $1 \mathrm{PhD}$ \\
\hline $\begin{array}{l}\text { Tshwane University of } \\
\text { Technology }\end{array}$ & $\begin{array}{l}\text { Magasa, L. } \\
\text { Mphahlele, M. } \\
\text { Awosejo, O. }\end{array}$ & $\begin{array}{l}2 \\
2 \\
1 \\
\end{array}$ & 1 Undergraduate & 1 Master's \\
\hline University of Pretoria & Kruger, J.P. & 1 & $\begin{array}{l}1 \text { Undergraduate } \\
2 \text { Postgraduate }\end{array}$ & $2 \mathrm{PhD}$ \\
\hline $\begin{array}{l}\text { University of the } \\
\text { Witwatersrand }\end{array}$ & & & & $2 \mathrm{PhD}$ \\
\hline University of Cape Town & & & & $1 \mathrm{PhD}$ \\
\hline
\end{tabular}


skills. These were generally taught by CI consultants, practitioners, and academics. The most prominent CI training courses and conferences in terms of number and scope of were IIR (now Informa) and Marcus Evans. These and other conference/seminar companies would typically organize a CI conference and contact trainers, consultants, and others, and ask them to present at conferences. They would also issue a call for trainers and speakers for these conferences. In addition, each would offer participants a CI seminar for an additional fee.

In the late 1990s, several of these conferences were held each year. However, a web search of current courses in CI presented by Informa ${ }^{7}$, Marcus Evans ${ }^{8}$, and Markex (marketing, promotions, and special events and exhibitions) yielded no results in South Africa. It should be noted, though, that seminars were identified during our search of many other countries. Such a result normally indicates that these seminar-focused firms have assessed that there is not a lot of demand for CI seminars in South Africa. This should be the focus of future research as the lack of CI conferences and workshops in South Africa runs contrary to the results in the other sections (CI practice and CI in academia).

The absence of activity could be ascribed to various factors. The lack of strong industry and professional leadership in CI has led to a diminished platform for CI in South Africa. Knowledge Management $(\mathrm{KM})$ and Business Intelligence (BI) have traditionally had stronger public platforms for the promotion of products and software-related services. Furthermore, the 2008 financial crisis and the concomitant budgetary constraints on corporate funding for CI decreased CI activity. It is also true, judging by the number of jobs advertised that include $\mathrm{CI}$ and the wider terms like market intelligence, competitor intelligence, and marketing intelligence, that $\mathrm{CI}$ is being practiced ubiquitously at corporate organizations (see CI practices). The absence of training by training firms is indicative of a lack of interest on the one hand but could also be a sign that there is no longer interest in being taught the basic principles of CI. The provision of training in more advanced CI activities and analysis including Trade Show Intelligence is lacking.

\section{Industry Associations}

The methodology used to identify CI professional associations in South Africa was primarily a review of the literature on past studies, focusing on the practice of CI in South Africa and the researcher's personal experience of, on the one hand, being a member of a particular professional association and, on the other hand, of establishing and launching one of the CI professional associations in South Africa.

Regarding professional CI associations in South Africa, with the increased attention being given to the subject of CI, various professional groups were established in South Africa in the early 2000s [Strauss, $\mathrm{Du}$ Toit, 2010]. Examples of such bodies included the Society for Competitive Intelligence Professionals (SCIP) Southern Africa (SCIPSA), the South African Society of Competitive Intelligence Professionals (SAACIP), and the Knowledge Management Society of South Africa (KMSSA). The authors also found that due to membership numbers being very low in 2008, none of these CI bodies were functioning [Strauss, Du Toit, 2010]. SAACIP was in essence driven by a consulting company while SCIP South Africa was more an academe-/practitioner-driven body. Today only two South African members were identified in the SCIP membership database.

This lack of a professional body means that there is no list of practicing South African CI professionals available. In response to this, the Strategic Competitive Intelligence Professionals - which underwent a name change in 2015, having previously been the Society for Competitive Intelligence Professionals (SCIP) - re-launched the South African Chapter which had first been launched in the early 2000s. The chapter hosted regular seminars and helped researchers and practitioners from industry remain in touch with new developments in CI. The SCIP South African Chapter also planned and hosted the first Africa Summit in October 2014 in Pretoria with the theme "Competitive Strategies as Practiced in Emerging African Markets" and the second Africa Summit in 2016 with the theme "Collaborative Intelligence for Africa's Development" hosted by UNISA. The majority of the members of the Chapter were from SOEs such as Eskom and Transnet, and from the banking, mining, consulting, and pharmaceutical industries.

In 2013, SCIP South Africa Chapter had 20 members. The membership increased to 41 members by 2016. Several SCIP conferences and chapter meetings were held in South Africa between 2014 and 2106 . By 2020, however, membership had decreased to the current two registered members. With SCIP South Africa facing membership problems and other challenges, there is no peer group or industry association for CI practitioners in South Africa. This also means that CI practitioners in the country have lost one of the avenues for gaining CI knowledge and training (through SCIP conferences, chapter meetings, and training programs).

In summary, South Africa's CI ecosystem appears to have a very limited number of CI consultancies compared to the early days, no CI conferences/workshops currently on offer, and only limited association activity. South African CI professionals therefore would have to turn to related areas or go outside the country to access any of these services. 


\section{Conclusions and Areas for Further Research}

This study was aimed at extending the CI business ecosystem concept [Calof, Brouard, 2004; Calof, Vibert, 2018] to South Africa. We identified and describe the CI business ecosystem in South Africa.

CI practice: Firms and Jobs. The authors found that there is a broad cross-section of firms, both in terms of sector and size, practicing CI in South Africa. Furthermore, the current survey found a high level of CI formality now in CI practice compared to the 2014 and 2015 studies, with respondents using a wide range of primary and secondary information sources as well as analytical techniques. South African firms appear to be more advanced than firms in other parts of Africa when it comes to CI practice. However, CI activities tend to be performed within units/departments with names like market insight and business intelligence - more so, in fact, than the more traditional competitive intelligence unit. At the government level, there is evidence of some $\mathrm{CI}$ activities at the national, provincial, and stateowned enterprise levels, but these activities are not widespread and relatively basic in practice. In terms of jobs, supporting the findings in CI practice is evidence of several CI jobs and CI job titles throughout the main economic areas in South Africa. However, in many cases the jobs are not denoted as "competitive intelligence"; rather, competitive intelligence skills are requested or the ability to conduct competitive intelligence activities within business development, market insight, and strategic marketing units. Therefore, the study found evidence of a widening of job descriptions and deeper entrenchment of $\mathrm{CI}$ and CI-related activities. Using the exact phase "competitive intelligence" in the job title resulted in far fewer results. It would be valuable to gain an understanding of the CI job and skills situation in the various economic sectors in South Africa.

CI practice: Government. Intelligence as a wider concept is still largely seen as a political and military effort in government departments in South Africa. There is no emphasis upon CI at any government level but departments such as the Department of Trade, Industry and Competition (DTIC) and the Department of Agriculture, Forestry and Fisheries have CI programs and have undergone training including on Trade Show Intelligence on an ad hoc basis. There is evidence of CI within the State-Owned Enterprises. Within the DTIC, there is similar evidence of CI initiatives in the Industry and Export Associations.

CI Support: Academe. Over more than two decades there has been a significant increase in academic CI activity. The academics at South African institutions have written 88 academic articles and the increase over two decades has been substantial. The number of universities offering courses in CI has doubled since the previous studies were conducted, with several universities presenting CI and CI-related lectures as part of other courses. These activities collectively have been producing CI Master's and PhD students, CI graduates who can work at South African firms and CI knowledge that can be used to enhance South African and other countries' firm practice.

CI Support: Consultants, Training, Workshops, and Conferences. The study noted only two consultancies specializing in CI. However, the study did find several consultancies that offer CI services; these, however, are not specialized CI consultancies but rather general consultancies. There has been a significant decline in offerings of CI training, workshops, and conferences. From what used to be significant activity in each of these areas in the late 1990s and early 2000s, the web search found no such activity for 2019/2020.

CI Support Activities: CI Industry Associations. Similar to the results listed above, from what were once thriving CI industry associations (SCIPSA and SAACIP) in the late 1990s and early 2000s, the study noted only two South African SCIP members while SAACIP no longer exists.

In terms of future research, it is suggested that a CI business ecosystem study be done in other countries, perhaps other African countries. This kind of research will help increase the generalizability of the CI business ecosystem concept.

The changes reported in this study in terms of the decline in associations, conferences, workshops, and CI consultancies could also be the focus of future research. How has this impacted the overall CI business ecosystem? Has the growth in CI in academia compensated for this?

Future research should also examine the relationship between CI business ecosystem elements and organizational CI practice. For example, does strong CI academic support or CI government support lead to good firm CI practice? This paper has not looked at CI performance, but perhaps future studies should look at the impact of the CI business ecosystem upon CI performance.

Finally, the study noted that there are many other "terms" being used for competitive intelligence, with departments responsible for CI activities being called market insight or business intelligence, as well as competitive intelligence, and the jobs requiring CI skills straddling market research, insight, strategy, and other areas. Perhaps the reason for the findings relating to associations, consulting, workshops, and so on is not that there is a decline in CI activities in these areas but that associations, consultan- 
cies, and so forth that have insight and intelligence in their names are part of the CI business ecosystem and are performing these activities. Expanding CI to include market intelligence and competitor intelligence was done in the jobs portion of the CI practice section of this study and it resulted in a tripling of the number of jobs identified. Future research in all areas of the CI business ecosystem research should consider adding market foresight, business intelligence, and similar terms to the CI business ecosys- tem. It might well be that including these terms will produce a more in-depth view and understanding of the CI business ecosystem. Expanding the terms used in future studies could produce a truer picture of the CI business ecosystem.

The study was prepared within the framework of the Basic Research Program at the National Research University HSE and supported within the framework of a subsidy by the Russian Academic Excellence Project "5-100."

\section{References}

Barnea A. (2016) Study on Competitive Intelligence in Israel. Journal of Intelligence Studies in Business, vol. 6, no 2, pp. 5-16.

Calof J.L., Arcos R., Sewdass N. (2018) Competitive intelligence practices of European firms. Technology Analysis \& Strategic Management, vol. 30, no 6, pp. 658-671. Available at: https://doi.org/10.1080/09537325.2017.1337890, accessed 08.02.2020.

Calof J.L., Brouard F. (2004) Competitive Intelligence in Canada. Journal of Competitive Intelligence and Management, vol. 2, no 2, pp. 1-21.

Calof J.L., Vibert C. (2018) Competitive intelligence in Canada. Revue Internationale d'Intelligence Economique (R2IE), vol. 10, no 2, pp. 55-67.

Crayon (2020) State of Competitive Intelligence. Available at: https://www.crayon.co/state-of-competitive-intelligence, accessed 02.02.2020.

Dishman P.L., Calof J.L. (2008) Competitive intelligence: A multiphasic precedent to marketing strategy. European Journal of Marketing, vol. 42, no 7/8, pp. 766-785.

Drieman J. (2018) Global Intelligence Survey 2017 Highlights. Competitive Intelligence, vol. 21, no 2, pp. 52-60.

Du Toit A.S.A. (2015) Using environmental scanning to collect strategic information: A South African survey. International Journal of Information Management, vol. 36, no 1, pp. 16-24. Available at: https://doi.org/10.1016/j.ijinfomgt, accessed 08.02.2020.

Du Toit A.S.A., Sewdass, N. (2014) Competitive intelligence in Morocco. African Journal of Library, Archives and Information Science, vol. 24, no 1, pp. 3-13.

Fehringer D., Hohhof B., Johnson T. (eds.) (2006) State of the art competitive intelligence. Competitive Intelligence Foundation Research Report, Alexandria, VA: Society of Competitive Intelligence Professionals.

Garcia-Alsina M., Cobarsí-Morales J., Ortoll E. (2016) Competitive intelligence theoretical framework and practices. Aslib Journal of Information Management, vol. 68, no 1, pp. 57-75. Available at: http://dx.doi.org/10.1108/AJIM-04-2015-0061, accessed 25.02.2020.

GCIS (2019) South Africa Yearbook 2018/9. Government Communication and Information System (GCIS). Available at: https://www.gcis.gov.za/south-africa-yearbook-2018/19, accessed 10.02.2020.

Glitman E. (2010) SCIP 2010 Conference Award Recipients. SCIP Insight, vol. 3, no 3.

Hayes A. (2019) Business Ecosystem. Available at: https://www.investopedia.com/terms/b/business-ecosystem.asp, accessed 10.03.2020.

Hult G.T.M., Gonzalez-Perez M.A., Lagerström K. (2020) The theoretical evolution and use of the Uppsala Model of internationalization in the international business ecosystem. Journal of International Business Studies, vol. 51, pp. 38-49. Available at: https://doi.org/10.1057/s41267-019-00293-x, accessed 02.04.2020.

Mirum (2020) The SCIP definition of Competitive Intelligence. Available at: http://competitive-intelligence.mirum.net/, accessed 30.03.2020.

Moore J. (1993) Predators and Prey: A New Ecology of Competition. Harvard Business Review, May/June 1993. Available at: https://hbr.org/1993/05/predators-and-prey-a-new-ecology-of-competition, accessed 11.05.2020.

Muller M.-L. (1999) SA: An emerging CI Player. Competitive Intelligence Review, vol. 10, no 4, pp. 74-78.

Muller M.-L., Viviers W. (2004) The Evolution of Competitive Intelligence in South Africa: Early 1980s-2003. Journal of Competitive Intelligence and Management, vol. 2, no 2, pp. 53-67. 
Munoz-Canavate A., Alves-Albero P. (2017) Competitive intelligence in Spain: A study of a sample of firms. Business Information Review, vol. 34, no 4, pp. 194-204. Available at: https://doi.org/10.1177/0266382117735982, accessed 25.02.2020.

Nasri W. (2011) Competitive intelligence in Tunisian companies. Journal of Enterprise Information Management, vol. 24, no 1, pp. 53-67. Available at: https://doi.org/10.1108/17410391111097429, accessed 25.02.2020.

Nenzhelele T.E. (2016) Competitive intelligence practice in the South African property sector. South African Journal of Information Management, vol. 18, no 2, art. 711, pp. 1-11.

Pellissier R., Nenzhelele T.E. (2013) Towards a universal competitive intelligence process model. South African Journal of Information Management, vol. 15, no 2, art. 567. Available at: https://sajim.co.za/index.php/sajim/article/view/567/657, accessed 03.02.2020.

Sewdass N., Du Toit A.S.A. (2014) Current state of competitive intelligence in South Africa. International Journal of Information Management, vol. 34, no 2, pp.185-190.

Sewdass N., Du Toit A.S.A. (2015) Competitive Intelligence in emerging economies: A comparative study between Brazil and South Africa. TD The Journal of Transdisciplinary Research in Southern Africa, vol. 11, no 1, pp. 113-132.

Strauss A.C., Du Toit A.S.A. (2010) Competitive intelligence skills needed in South Africa. Aslib Proceedings, vol. 62, no 3, pp. 302-320.

Viviers W., Saayman A., Muller M.-L. (2004) Competitive intelligence in South Africa: 1999-2002 and beyond. Africa Insight, vol. 34, no 2/3, pp. 90-96.

Viviers W., Saayman A., Muller M.-L., Calof J. (2002) Competitive intelligence practices: A South African study. South African Journal of Business Management, vol. 33, no 3, pp. 27-37. 